\title{
Analisis Faktor-Faktor Yang Mempengaruhi Produksi Usahatani Bawang Merah Di Desa Lam Manyang Kecamatan Peukan Bada
}

\section{(Analysis of Factors Affecting the Production of Farm Shallots In the village of Lam Manyang Bada subdistrict Peukan)}

\author{
Muhammad Rijal ${ }^{1}$, Fajri Jakfar ${ }^{1}$, Widyawati ${ }^{1}$ \\ ${ }^{1}$ Program Studi Agribisnis, Fakultas Pertanian, Universitas Syiah Kuala
}

\begin{abstract}
Absrtak- Bawang merah merupakan salah satu usahatani sayuran unggulan yang sejak lama telah diusahakan oleh petani. Bawang merah yang terdapat di Desa Lam Manyang dengan luas lahan berkisar sebesar $10 \mathrm{Ha}$, dengan hasil yang di dapatkan setiap panen berkisar antara 7-8 ton per hektar. Hal ini tentu memiliki prospek pasar yang sangat baik dan perlu untuk terus dikembangkan. Tujuan penelitian ini untuk mengetahui faktor - faktor yang mempengaruhi produksi bawang merah di Desa Lam Manyang Kecamatan Peukan Bada Kabupaten Aceh Besar. Pengambilan sampel dilakukan secara sensus. Metode sensus yaitu metode penentuan sampel dengan menggunakan semua anggota populasi. Metode analisis yang digunakan dalam penelitian ini adalah Analisis Fungsi Cobb-Douglas, yaitu untuk mengetahui faktor-faktor produksi yang berpengaruh terhadap produksi usahatani bawang merah. Hasil pengujian secara serempak yang dilakukan dengan uji F statistik, menunjukkan variabel modal, luas Lahan, pupuk, bibit dan tenaga kerja berpengaruh secara nyata terhadap produksi bawang merah di Desa Lam Manyang.
\end{abstract}

Kata Kunci : Usahatani, Bawang Merah, Produksi, Modal, Luas Lahan, Pupuk, Bibit, dan Tenaga Kerja

Abstract- Onion is the one of vegetable farming since along time ago that used by farmer. Onion in Lam manyang with $10 \mathrm{Ha}$ land, can make production in every harvest season among 7-8 ton a hectare. It certainly has a very good market prospects and need to continue to be developed. The purpose of this study to determine the factors that affect the production of onion in the Lam Manyang, Peukan Bada of Aceh Besar. Sampling was done by census. Method census sampling method with the use of all members of the population. The analytical method used in this research is the analysis of Cobb-Douglas function, to known production factors that affected to onion farming production. The test results are simultaneously performed by F test statistic, showing a variable capital, vast land, fertilizer, seed and labor significantly affect the production of onion in Lam Manyang.

Keyword : Analyzed, Affected, Production, Capital, Fertilizer, Seed, Labour 


\section{PENDAHULUAN}

Indonesia selama ini dikenal sebagai negara yang memiliki sumber daya alam yang melimpah, sehingga sering disebut sebagai negara agraris yang berarti negara yang mengandalkan sektor pertanian baik sebagai sumber mata pencaharian maupun sebagai penopang pembangunan. Salah satu sub sektor pertanian yang terus dituntut untuk berperan dalam perekonomian nasional guna mengentaskan kemiskinan, menyediakan lapangan kerja dan meningkatkan pendapatan adalah sub sektor pertanian pangan yang salah satu komoditas yang biasa diusahakan petani kecil adalah bawang merah.

Bawang merah merupakan salah satu usahatani sayuran unggulan yang sejak lama telah diusahakan oleh petani secara intensif. Usahatani sayuran ini termasuk ke dalam kelompok rempah tidak bersubstitusi yang berfungsi sebagai bumbu penyedap makanan serta obat tradisional. Usahatani ini juga merupakan sumber pendapatan dan kesempatan kerja yang memberikan kontribusi cukup tinggi terhadap perkembangan ekonomi wilayah (Balitbang Pertanian, 2005).

Produksi bawang merah di Indonesia masih bersifat musiman seperti hasil pertanian pada umumnya. Hal ini menyebabkan kebutuhan bawang merah masyarakat Indonesia di luar musim panen tidak dapat dipenuhi sehingga untuk memenuhinya perlu dilakukan tindakan impor. Pemerintah melakukan impor bawang merah untuk menjaga ketersediaan bawang merah dalam negeri serta kestabilan harga pasar (Bank Indonesia, 2013).

Dalam konteks teori produksi kaitannya dengan pertanian, faktor penting dalam pengelolaan sumberdaya produksi adalah faktor alam (tanah), modal, dan tenaga kerja, selain itu juga faktor manajemen (Mubyarto, 1994). Diantara berbagai faktor produksi yang tersebut di atas terdapat faktor produksi yang sangat menentukan dalam usahatani bawang merah yaitu meliputi luas lahan, benih, tenaga kerja, pupuk (Urea, NPK, Kandang) dan modal.

Salah satu sentra produksi bawang merah di Kabupaten Aceh Besar adalah Kecamatan Peukan Bada karena daerah ini memiliki kondisi tanah yang subur daniklim yang mendukung untuk bercocok tanam. Usahatani bawang merah banyak diusahakan oleh para petani di Kecamatan Peukan Bada, guna memanfaatkan sumber daya lahan dan untuk memperoleh pendapatan dalam memenuhi kebutuhan hidupnya. Bawang merah dihasilkan hampir di seluruh wilayah Aceh Besar, Kecamatan Peukan Bada termasuk salah satu daerah di Provinsi Aceh yang masyarakatnya masih aktif mengusahakan usahatani bawang merah sebagai usahatani utamanya.

Usahatani bawang merah di Desa Lam Manyang merupakan sentra produksi bawang merah terbesar dan menjadi tumpuan produksi bawang merah di Kecamatan Peukan Bada. Menurut data Badan Pusat Statistik (BPS, 2015) berbagai hasil pertanian yang terdapat di Kecamatan Peukan Bada salah satunya sektor andalan yaitu bawang merah yang terdapat di Desa Lam Manyang dengan luas lahan berkisar sebesar $10 \mathrm{Ha}$, dengan hasil yang di dapatkan setiap panen berkisar antara 7-8 ton per hektar. Hal ini tentu memiliki prospek pasar yang sangat baik dan perlu untuk terus dikembangkan untuk kesejahteraan petani, adapun komiditi bawang merah selain di pasarkan di Kabupaten Aceh Besar juga mampu menembus pasar di Kota Banda Aceh dan beberapa kabupaten atau kota lainnya. Oleh karena itu faktor- 
faktor yang mempengaruhi produksi usahatani bawang merah di Desa Lam Manyang sangat penting untuk diketahui sebagai bahan pertimbangan dalam mengambil keputusan tentang penggunaan teknologi dan kebijakan yang bertujuan untuk meningkatkan produksi sekaligus meningkatkan keuntungan petani. Setiap petani bawang merah tentu mengharapkan produksi yang tinggi dan sekaligus keuntungan yang memadai.

Berdasarkan hasil survei, alasan petani menanam bawang merah karena tertarik dengan nilai ekonomis yang tinggi dan jika dilihat dari permintaan pasar yang semakin meningkat menunjukkan bahwa bawang merah sangat di butuhkan untuk keperluan sehari-hari. Untuk melihat seberapa besar keberhasilan usahatani bawang merah yang dilakukan oleh petani, maka timbul pertanyaan sebagai berikut: Apa saja faktor-faktor yang mempengaruhi produksi bawang merah di desa lam manyang kecamatan peukan bada. Untuk menjawab pertanyaan tersebut, maka penulis melakukan penelitian dengan judul "Analisis Faktor-fakor Yang Mempengaruhi Usahatani Bawang Merah Di Desa Lam Manyang Kecamatan Peukan Bada Kabupaten Aceh Besar".

\section{Lokasi, Objek, dan Ruang Lingkup Penelitian \\ METODE PENELITIAN}

Penelitian ini dilakukan Di Desa Lam Manyang dengan pertimbangan bahwa Desa ini merupakan sentra produksi bawang merah Di Kecamatan Peukan Bada Kabupaten Aceh Besar. Objek penelitian ini adalah petani yang memiliki usaha budidaya bawang merah Di Desa Lam Manyang Kecamatan Peukan Bada. Ruang lingkup penelitian terbatas pada faktor-faktor yang mempengaruhi produksi usahatani bawang merah Di Desa Lam Manyang Kecamatan Peukan Bada.

\section{Metode Penelitian dan Pengumpulan Data}

Metode pengambilan sampel dilakukan secara sensus yaitu metode penentuan sampel dengan menggunakan semua anggota populasi. Dalam penelitian ini karena jumlah populasinya sedikit (terbatas) sehingga tidak memungkinkan untuk menggunakan sampel (sugiyono, 2008).

Pengumpulan data yang digunakan dalam penelitian ini terdiri dari data primer dan data sekunder. Data primer yaitu data yang diperoleh dari pengamatan langsung di lapangan dan wawancara terhadap pengelola usahatani budidaya jambu madu deli hijau. Data sekunder yaitu data yang diperoleh dari perpustakaan, instansi terkait, browsing internet atau literatur yang terkait dalam penelitian ini.

\section{Metode Analisis}

Berdasarkan data yang telah dikumpulkan di lapangan, dipindahkan dan ditabulasikan kemudian diolah dalam bentuk Fungsi Cobb-Douglas.

Analisis fungsi cobb-douglas merupakan suatu teknik matematika dalam mengetahui faktor-faktor produksi yang berpengaruh terhadap produksi usahatani bawang merah atau dengan kata lain merupakan alat analisis yang digunakan untuk menjelaskan hubungan faktor-faktor produksi (X) dengan produksi (Y). 
Secara matematik bentuk persamaan analisis fungsi Cobb-Douglas dapat ditulis sebagai berikut (Soekartawi, 2002): $\mathrm{Y}=\mathrm{aX}_{1}{ }^{\mathrm{b} 1}, \mathrm{X}_{2}{ }^{\mathrm{b} 2}, \mathrm{X}_{3}{ }^{\mathrm{b} 3}, \mathrm{X}_{4}{ }^{\mathrm{b} 4} \ldots \ldots . \mathrm{X}_{\mathrm{n}}{ }^{\mathrm{bn}} \mathrm{e}$

Fungsi Cobb-Douglas ditransformasikan ke dalam bentuk logaritma untuk mendapatkan persamaan yang linier. Setelah diubah dalam bentuk logaritma diperoleh persamaan regresi linier berganda sebagai berikut:

$\operatorname{Ln} Y=\operatorname{Ln} a+b 1 \operatorname{Ln} X 1+b_{2} \operatorname{Ln} X_{2}+b_{3} \operatorname{Ln} X_{3}+b_{4} \operatorname{Ln} X_{4}+b_{5} \operatorname{Ln} X_{5}+e$

Keterangan:

\section{Uji Hipotesa $\mathbf{F}$}

$$
\begin{array}{ll}
\mathrm{Y} & =\text { Produksi Bawang Merah }(\mathrm{Kg} / \mathrm{Ha} / \mathrm{MT}) \\
\mathrm{X}_{1} & =\text { Modal }(\mathrm{Rp} / \mathrm{Ha} / \mathrm{MT}) \\
\mathrm{X}_{2} & =\text { Luas Lahan }(\mathrm{Ha}) \\
\mathrm{X}_{3} & =\text { Pupuk }(\mathrm{Kg} / \mathrm{Ha} / \mathrm{MT}) \\
\mathrm{X}_{4} & =\text { Bibit }(\mathrm{Kg} / \mathrm{Ha} / \mathrm{MT}) \\
\mathrm{X}_{5} & =\text { Tenaga Kerja }(\mathrm{HKP} / \mathrm{MT}) \\
\mathrm{a} & =\text { Konstanta } \\
\mathrm{Ln} & =\text { Logaritma Natural } \\
\mathrm{e} & =\text { error }
\end{array}
$$

Untuk mengetahui peranan variabel yang mempengaruhi terhadap variabel yang dipengaruhi secara serempak (bersama-sama) digunakan uji " $F$ " dengan menuuggunakan rumus (Sudjana, 2005) sebagai berikut:

Dimana:

$$
\mathrm{F}_{\text {Cari }}=\frac{\mathrm{R}^{2} / \mathrm{K}}{\left(1-\mathrm{R}^{2}\right) /(\mathrm{n}-\mathrm{k}-1)}
$$

$\mathrm{R}^{2} \quad=$ Koefisien determinasi

$\mathrm{k}=$ Jumlah variabel bebas

$\mathrm{n} \quad=$ Jumlah sampel

Pengujian hipotesis melalui uji-F yaitu membandingkan $F_{\text {hitung }}$ dengan $F_{\text {tabel }}$. Apabila hasil perhitungan menunjukkan:

$\mathrm{F}_{\text {hitung }}>\mathrm{F}_{\text {Tabel}}$, pada taraf nyata 0,05 maka $\mathrm{H}_{\mathrm{o}}$ ditolak dan $\mathrm{H}_{\mathrm{a}}$ diterima , berarti secara bersama-sama variabel bebas $(\mathrm{X})$ berpengaruh nyata terhadap variabel tidak bebas (Y).

$\mathrm{F}_{\text {hitung }}<\mathrm{F}_{\text {Tabel }}$, pada taraf nyata 0,05 maka $\mathrm{H}_{\mathrm{o}}$ diterima dan $\mathrm{H}_{\mathrm{a}}$ ditolak berarti secara bersama-sama variabel bebas $(\mathrm{X})$ berpengaruh tidak nyata terhadap variabel tidak bebas (Y).

\section{Uji Hipotesa $t$}

Untuk mengetahui pengaruh masing-masing variabel yang mempengaruhi terhadap variabel yang dipengaruhi secara parsial (terpisah) digunakan uji "t" dengan menggunakan rumus (Sudjana, 2005) sebagai berikut:

$$
\mathrm{t}_{\mathrm{cari}}=\frac{\mathrm{ai}}{\mathrm{SE}_{\mathrm{ai}}}
$$

Dimana:

ai $a_{i}=$ koefisien regresi yang dicari 
$\mathrm{SE}_{\mathrm{ai}}=$ standar error

Pengujian hipotesis melalui uji-t yaitu membandingkan $t_{\text {hitung }}$ dengan $t_{\text {tabel }}$. Apabila hasil perhitungan menunjukkan:

$t_{\text {hitung }}>\mathrm{t}_{\text {tabel}}$, pada taraf nyata 0,05 maka $\mathrm{H}_{\mathrm{o}}$ ditolak dan $\mathrm{H}_{\mathrm{a}}$ diterima, berarti secara individual variabel bebas $(\mathrm{X})$ berpengaruh nyata terhadap variabel tidak bebas $(\mathrm{Y})$.

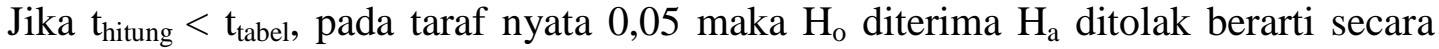
individual variabel bebas $(\mathrm{X})$ tidak berpengaruh nyata terhadap variabel tidak bebas (Y).

\section{Karakteristik Petani}

\section{HASIL DAN PEMBAHASAN}

Karakteristik petani adalah suatu keadaan petani pada usahatani bawang merah di daerah penelitian. Karakteristik yang dimaksud pada penelitian ini meliputi : Umur, Pendidikan, Pengalaman, dan Jumlah Tanggunggan. Karakteristik petani tersebut akan mempengaruhi terhadap kegiatan, keterampilan, dan kemampuan petani untuk mengkombinasikan penggunaan faktor-faktor produksi serta pengambilan keputusan dalam berusahatani yang kesemuanya ini bertujuan untuk meningkatkan produksi dan pendapatan petani.

\section{Modal}

Modal merupakan faktor yang sangat penting dalam suatu usaha budidaya tanaman bawang merah. Penggunaan modal ditujukan untuk meningkatkan produksi dan produktivitas kerja.

Berdasarkan hasil survei pada petani di Desa Lam Manyang bahwa modal yang dikeluarkan seluruh petani bawang merah yang berada di Desa Lam Manyang sebesar Rp. 451.183.750,-. Dengan jumlah ini dapat diartikan petani di Di Desa Lam Manyang sangat serius dalam usaha budidaya bawang merah. Modal yang digunakan oleh petani bawang merah di Desa Lam Manyang meliputi: pembelian bibit, pupuk, peralatan dan pembayaran upah tenaga kerja.

\section{Luas Lahan}

Luas lahan adalah besar kecilnya lahan yang digunakan petani untuk membudidayakan bawang merah. Luas lahan merupakan faktor yang sangat penting dalam menentukan jumlah produksi. Berdasarkan hasil penelitian bahwa jumlah luas lahan di Desa Lam Manyang sebesar 10 Ha. Sebagian besar petani bawang merah di daerah penelitian memiliki lahan sendiri dalam membudidayakan tanaman bawang merah. Rata-rata umur tanaman bawang merah di daerah penelitian adalah 90 hari untuk bisa dipanen dengan jarak tanam $10 \mathrm{~cm} \times 10 \mathrm{~cm}$.

\section{Bibit}

Bibit sangat menentukan produksi budidaya bawang merah. Bibit yang unggul cenderung dapat menghasilkan produksi kualitas yang baik, sedangkan bibit yang rentan terhadap penyakit dapat merugikan petani dikarenakan produksi yang kurang memuaskan.

Berdasarkan hasil penelitian bahwa jumlah bibit dari seluruh responden di Desa Lam Manyang sebesar $10.075 \mathrm{Kg}$ bibit. Dimana harga bibit berkisar Rp. 28.000,- per Kg yang dibeli oleh petani di Kabupaten Brebes, Jawa Tengah. Namun 
sekarang petani di Desa Lam Manyang sudah mampu untuk memproduksi bibit bawang merah sendiri dengan pengetahuan yang di dapat dari penyuluh pertanian setempat.

\section{Pupuk}

Pupuk merupakan unsur yang penting dalam meningkatkan produksi bawang merah. Pupuk yang digunakan petani di Desa Lam Manyang terdiri dari 3 macam, yaitu pupuk kandang, urea dan npk (natrium, phospat, kalium). Pemberian pupuk dengan komposisi yang tepat dapat meningkatkan produksi bawang merah. Berdasarkan hasil penelitian jumlah pupuk yang digunakan oleh petani bawang merah di Desa Lam Manyang sebanyak $14.605 \mathrm{Kg} / \mathrm{Ha}$ dengan penggunaan pupuk yang digunakan berjumlah sangat beragam tergantung pada luas lahan di setiap usahatani yang dilakukan.

\section{Tenaga Kerja}

Tenaga kerja adalah salah satu faktor produksi yang sangat penting dalam suatu usaha budidaya bawang merah. Tenaga kerja harus diperhitungkan dalam proses produksi, yaitu dalam jumlah yang efisien bukan hanya dilihat dari segi ketersediaannya tenaga kerja tetapi kualitas tenaga kerja tersebut. Umumnya tenaga kerja yang banyak digunakan dalam usahatani bawang merah adalah tenaga kerja pria yaitu pada saat persiapan lahan, persiapan bibit, penanaman, pemupukan, pemeliharaan serta panen dan penanganan pasca panen. Berikut tabel jumlah tenaga kerja pada lokasi penelitian.

Tabel 1. Penggunaan Tenaga Kerja pada Usahatani Bawang Merah di Desa Lam Manyang

\begin{tabular}{|c|c|c|c|c|}
\hline No & Kegiatan & DK (HOK) & LK (HOK) & $\begin{array}{c}\text { Jumlah } \\
\text { (HOK) }\end{array}$ \\
\hline 1. & Persiapan Lahan & 242 & 165 & 407 \\
\hline 2. & Persiapan Bibit & 72 & 24 & 96 \\
\hline 3. & Penanaman & 67 & 66 & 133 \\
\hline 4. & Pemupukan & 116 & 39 & 155 \\
\hline 5. & Pemeliharaan & 85 & 25 & 110 \\
\hline 6. & Panen dan Pasca Panen & 85 & 57 & 142 \\
\hline & Jumlah & 667 & 376 & 1043 \\
\hline & Rata-rata & 111 & 63 & 174 \\
\hline
\end{tabular}

Sumber: Hasil Penelitian, 2016 
Dari tabel 1 dapat dilihat bahwa jumlah HOK di Desa Lam Manyang sebanyak $1043 \mathrm{HOK}$, dimana kegiatan persiapan lahan sebanyak $407 \mathrm{HOK}$, persiapan bibit sebanyak $96 \mathrm{HOK}$, penanaman sebanyak $133 \mathrm{HOK}$, pemupukan sebanyak 155 HOK, pemeliharaan $110 \mathrm{HOK}$ serta penanganan panen dan pasca panen sebanyak 142 HOK.

Adapun hasil analisis dengan menggunakan cobb-douglass faktor-faktor yang mempengaruhi terhadap Produksi Bawang Merah di Desa Lam Manyang dapat dilihat pada tabel berikut.

Tabel 2. Hasil Analisis Pengaruh Modal Luas Lahan Pupuk Bibit Tenaga Kerja terhadap Produksi Bawang Merah di Desa Lam Manyang Kecamatan Peukan Bada Kabupaten Aceh Besar

\begin{tabular}{|c|c|c|c|c|c|}
\hline $\mathrm{F}_{\text {cari }}$ & \multicolumn{2}{|c|}{$=128.030$} & $\mathrm{~F}_{\text {tabel }}$ & \multicolumn{2}{|l|}{$=2.74$} \\
\hline $\mathrm{T}_{\text {tabel }}$ & \multicolumn{2}{|c|}{$=1.729$} & \multicolumn{3}{|c|}{ Taraf nyata $(\alpha)=0.05$} \\
\hline Variabel & Nama Variabel & Koefisien & $\begin{array}{c}\text { Std. } \\
\text { Error }\end{array}$ & $\mathbf{T}$ & Signifikan \\
\hline A & (constanta) & 2.856 & .742 & 3.849 & .001 \\
\hline $\mathrm{X} 1$ & Modal & .130 & .059 & 2.183 & .042 \\
\hline $\mathrm{X} 2$ & Luas Lahan & 1.298 & .178 & 1.272 & .000 \\
\hline $\mathrm{X} 3$ & Pupuk & 1.169 & .090 & 12.984 & .000 \\
\hline $\mathrm{X} 4$ & Bibit & 1.574 & .147 & 10.684 & .000 \\
\hline $\mathrm{X} 5$ & Tenaga Kerja & .002 & .031 & .057 & .955 \\
\hline
\end{tabular}

Sumber : Hasil Penelitian, 2016

Berdasarkan table 2 di atas di peroleh persamaan regresi linear sebagai berikut:

$\operatorname{LnY}=\operatorname{Ln} 2.856+0.130 \operatorname{LnX}_{1}+1.298 \operatorname{LnX}_{2}+1.169 \operatorname{LnX}_{3}+1,574 \operatorname{LnX}_{4}+0.002 \operatorname{LnX}_{5}$

Persamaan ini menunjukkan bahwa nilai konstanta sebesar 2.856 menyatakan bahwa apabila nilai variabel modal (X1), luas lahan (X2), pupuk (X3), bibit (X4), dan 
tenaga Kerja (X5) adalah konstant atau tetap maka akan meningkatkan produksi bawang merah sebesar $2.856 \mathrm{Kg} / \mathrm{Ha}$.

Untuk mengetahui variabel bebas terhadap variabel terikat dapat dilihat dari hasil pengujian secara serempak yang dilakukan dengan uji $\mathrm{F}$ statistik. Hasil yang didapat menunjukkan bahwa $\mathrm{F}_{\text {cari }}$ sebesar 128.030 dengan tingkat signifikan 0.000 dan $F_{\text {tabel }}$ sebesar 2.74 pada tingkat kepercayaan 95\%. Dengan kata lain $F_{\text {cari }}>F_{\text {tabel }}$ maka secara serempak variabel modal (X1), luas lahan (X2), pupuk (X3), bibit (X4) dan tenaga kerja (X5) berpengaruh secara nyata (terima Ha tolak H0) terhadap produksi bawang merah di Desa Lam Manyang.

Untuk melihat besarnya hubungan penggunaan faktor produksi (Y) dengan modal (X1), luas Lahan (X2), pupuk (X3), bibit (X4) dan tenaga kerja (X5) digunakan koefisien determinan $\left(\mathrm{R}^{2}\right)$. Nilai koefesien determinasi dari model ini sebesar 0.971 artinya bahwa $97.1 \%$ produksi bawang merah di Desa Lam Manyang di pengaruhi oleh faktor modal (X1), luas Lahan (X2), pupuk (X3), bibit (X4) dan tenaga kerja (X5), sedangkan 2.9\% dipengaruhi oleh variabel lain. Jika dalam keadaan konstan nilai elastisitas produksi berada pada daerah 1 karena memiliki nilai lebih dari satu, yaitu sebesar 2.856 .

Modal (X1)

Nilai koefisien modal adalah 0.130 . Ini artinya bahwa setiap penambahan 1 rupiah Modal, maka akan meningkatkan produksi bawang merah sebesar $0.130 \mathrm{Kg}$, dengan asumsi variabel lain tidak berubah atau konstant.

Pengujian statistik untuk Modal didapatkan $\mathrm{T}_{\text {cari }}$ sebesar $=2.183$ sedangkan $\mathrm{T}_{\text {tabel }}$ sebesar $=1.729$, hal ini menunjukkan $\mathrm{T}_{\text {cari }}>\mathrm{T}_{\text {tabel }}$ dengan tingkat kepercayaan 95\% (0,05). Ini artinya variabel modal berpengaruh nyata terhadap produksi bawang merah di Desa Lam Manyang.

Nilai elastisitas variabel modal terhadap produksi bawang merah mempunyai nilai elastisitas lebih kecil dari satu, yaitu 0,130 yang menandakan bahwa nilai elastisitas modal berada pada daerah III atau disebut dengan Decreasing return to scale.

\section{Luas Lahan (X2)}

Nilai koefisien luas lahan adalah 1.298. Ini artinya setiap penambahan 1 meter luas lahan maka akan meningkatkan produksi bawang merah sebesar $=1.298 \mathrm{Kg}$, dengan asumsi variabel ini tidak berubah atau konstant.

Pengujian statistik untuk luas lahan didapatkan $\mathrm{T}_{\text {cari }}$ sebesar $=1.272$ sedangkan $\mathrm{T}_{\text {tabel }}$ sebesar $=1,729$ hal ini menunjukkan $\mathrm{T}_{\text {cari }}<\mathrm{T}_{\text {tabel }}$ dengan tingkat kepercayaan 95\% $(0,05)$. Ini artinya variabel luas lahan tidak berpengaruh secara nyata terhadap produksi bawang merah di Desa Lam Manyang.

Nilai elastisitas variabel luas lahan terhadap produksi bawang merah mempunyai nilai elastisitas lebih dari satu, yaitu 1,298 yang menandakan bahwa nilai Elastisitas luas lahan berada pada daerah 1 atau disebut dengan increasing return to scale.

\section{Pupuk (X3)}

Nilai koefisien pupuk adalah 1.169. Ini artinya bahwa setiap penambahan 1 $\mathrm{Kg}$ pupuk, maka akan meningkatkan produksi bawang merah sebesar $1.169 \mathrm{Kg}$, dengan asumsi variabel lain tidak berubah atau konstant. 
Pengujian statistik untuk pupuk didapatkan $\mathrm{T}_{\text {cari }}$ sebesar $=12.984$ sedangkan $\mathrm{T}_{\text {tabel }}$ sebesar $=1,729$, hal ini menunjukkan $\mathrm{T}_{\text {cari }}>\mathrm{T}_{\text {tabel }}$ dengan tingkat kepercayaan 95\% (0,05). Ini artinya variabel pupuk berpengaruh nyata terhadap produksi bawang merah di Desa Lam Manyang.

Nilai elastisitas variabel luas lahan terhadap produksi bawang merah mempunyai nilai elastisitas lebih dari satu, yaitu 1,169 yang menandakan bahwa nilai elastisitas pupuk berada pada daerah 1 atau disebut dengan Increasing return to scale.

\section{Bibit (X4)}

Nilai koefisien bibit adalah 1.574. Ini artinya bahwa setiap penambahan $1 \mathrm{Kg}$ bibit, maka akan meningkatkan produksi bawang merah sebesar $1.574 \mathrm{Kg}$, dengan asumsi variabel lain tidak berubah atau konstant. Jumlah produksi bawang merah dapat di lihat dari jumlah bibit yang ditanam. Semakin banyak jumlah bibit yang ditanam maka semakin banyak pula jumlah produksi yang dihasilkan namun apabila kualitas bibit tidak baik, mudah terserang penyakit dan membawa virus kepada tanaman bawang merah yang lain maka jumlah produksi yang dihasilkan sedikit.

Pengujian statistik untuk bibit didapatkan $\mathrm{T}_{\text {cari }}$ sebesar $=10.684$ sedangkan $\mathrm{T}_{\text {tabel }}$ sebesar $=1,729$, hal ini menunjukkan $\mathrm{T}_{\text {cari }}>\mathrm{T}_{\text {tabel }}$ dengan tingkat kepercayaan 95\% (0,05). Ini artinya variabel bibit berpengaruh nyata terhadap produksi bawang merah di Desa Lam Manyang.

Nilai elastisitas variabel bibit terhadap produksi bawang merah mempunyai nilai elastisitas lebih dari satu, yaitu 1,574 yang menandakan bahwa nilai elastisitas bibit berada pada daerah 1 atau disebut dengan Increasing return to scale.

\section{Tenaga Kerja (X5)}

Nilai koefisien tenaga kerja adalah 0.002. Ini artinya bahwa setiap penambahan 1 tenaga kerja, maka akan meningkatkan produksi bawang merah sebesar $0.002 \mathrm{Kg}$, dengan asumsi variabel lain tidak berubah atau konstant.

Pengujian statistik untuk tenaga kerja didapatkan $\mathrm{T}_{\text {cari }}$ sebesar $=0.057$ sedangkan $\mathrm{T}_{\text {tabel }}$ sebesar $=1,729$, hal ini menunjukkan $\mathrm{T}_{\text {cari }}<\mathrm{T}_{\text {tabel }}$ dengan tingkat kepercayaan $95 \%(0,05)$. Ini artinya variabel tenaga kerja tidak berpengaruh nyata terhadap produksi bawang merah di Desa Lam Manyang.

Nilai elastisitas variabel tenaga kerja terhadap produksi bawang merah mempunyai nilai elastisitas lebih kecil dari satu, yaitu 0,002 yang menandakan bahwa nilai elastisitas tenaga kerja berada pada daerah III atau disebut dengan decreasing return to scales.

\section{KESIMPULAN DAN SARAN}

Pengujian secara serempak pada variabel modal, luas lahan, pupuk, bibit dan tenaga kerja berpengaruh secara nyata terhadap peningkatan produksi bawang merah di Desa Lam Manyang Kecamatan Peukan Bada. Pengujian secara parsial didapatkan variabel modal, luas lahan, pupuk, dan bibit berpengaruh secara nyata terhadap produksi bawang merah di Desa Lam Manyang, sedangkan pada variabel tenaga 
kerja tidak berpengaruh nyata terhadap produksi bawang merah di Desa Lam Manyang.

Dalam melakukan usaha budidaya bawang merah petani sebaiknya memperhatikan segala aspek pemeliharaan budidaya bawang merah. Hal ini dikarenakan agar keberlangsungan budidaya bawang merah dapat bertahan dalam jangka waktu yang lama. Bertahannya budidaya bawang merah maka akan mempengaruhi produksi dan juga keberlangsungan hidup petani bawang merah itu sendiri.Selain faktor internal petani bawang merah harus memperhatikan faktor eksternal seperti penyakit ataupun segala sesuatu yang dapat mengurangi produksi bawang merah.

\section{DAFTAR PUSTAKA}

Badan Pusat Statistik, 2015. Kabupaten Aceh Besar Dalam Angka, Provinsi Aceh.

Balitbang Pertanian. 2005. Prospek dan Arah Pengembangan Agribisnis Bawang Merah. Departemen Pertanian. Jakarta.

Bank Indonesia. 2013. Pola Pembiayaan Usaha Kecil Menengah Usaha Budidaya Bawang Merah. Departemen Pengembangan Akses Keuangan dan UMKM. Jakarta.

Mubyarto, 1994. Pengantar Ekonomi Pertanian. Jakarta : LP3ES

Sudjana. 2005. Metoda Statistika. Bandung: Tarsito.

Sugiyono, 2008. Metode Penelitian Kunatitatif Kualitatif dan R\&D. Alfabeta. Bandung 
Jurnal IImiah Mahasiswa Pertanian Unsyiah

Volume 1, Nomor 1, November 2016

www.jim.unsyiah.ac.id/JFP 